\title{
Josephine's Journey: Gender-based Violence and Marian Devotion in Urban Papua New Guinea
}

\author{
Anna-Karina Hermkens \\ Radboud University Nijmegen
}

\begin{abstract}
This article deals with how, in the urban setting of Madang, Papua New Guinea, Marian devotion is deployed in response to domestic and gender-based violence. While providing insight into the lived religious experiences of Catholic women living in Madang, this article shows how Mary empowers her followers to resist violence, yet, at the same time, paradoxically, is instrumental in sanctioning women to tolerate violence. Josephine's 'journey of violence' reveals not only Josephine's turning to Mary, but more so, her negotiations with values belonging to different cultural logics. Caught between 'tradition', Christianity and 'modernity', Josephine and other Catholic women engage in painful processes of self-analysis and self-transformation to adapt to and change their situation. In these processes, Mary is used as a role model.

Key words: Christianity, Marian devotion,domestic violence, modernity, Papua New Guinea.
\end{abstract}

\section{INTRODUCTION}

The association between Mary, the mother of Jesus, and violence seems not very obvious, but in Papua New Guinea, as elsewhere in the world, people turn to Mary in order to seek a solution for the problems they face. Josephine's 'journey of violence' deals with how in the urban setting of Madang, Marian devotion is deployed in response to domestic and genderbased violence. In following the experiences and perceptions of Josephine, a 49-old educated woman working at the Catholic Diocesan's Health office in Madang, this article acknowledges the current debate on Christianity in Papua New Guinea and, in particular, the urge for a more intensive anthropological investigation of the experience of Christianity by Melanesians (for example Barker 1990:9, 1992).

Various scholars have since responded to Barker's call, but most of these studies (for example Goddard \& Van Heekeren 2003; Jebens 2005; Robbins 2004) have focused on rural indigenisations of Christianity and processes of transformation. Urban experiences and constructions of Christianity remain largely un-addressed. Moreover, little is known about the impact and nature of Catholicism and in particular of Marian devotion in urban settings. Josephine's experiences give insight into how Marian devotion is practised and used by individual women and Church clergy to provide a way for them to cope with various forms of violence.

In the following sections, I will give an overview of the various acts of violence Papua New Guinean women like Josephine face, and how these acts result in a 'state of violence' 
(Brown 1987) that shapes women's lives. By elaborating on the setting of Madang, it is shown that this 'state of violence' is part of a specific urban sociality that calls for a redefinition of family relations, gender roles and kinship relations, and which is coloured by other morally troubling issues such as gender violence and HIV/AIDS. In order to address these issues, both men and women turn to Mary in order to seek guidance, help and empowerment.

However, as already elucidated by studies on Mary, the role of Mary is not straightforward as she is seen to both empower and dis-empower her followers (Hermkens 2007a, 2007b; Ruether 1993). In the small town of Madang, Mary not only exercises power in her capacity of strengthening and protecting her female followers against violence. She is also instrumental in the assertion of authority and obedience and, as such, of facilitating violence against women. Mary's role is complex as she herself is part of the many struggles urban women face. Caught between 'traditional', Christian and 'modern' values, Josephine and other Catholic women engage in painful processes of subjectivation and self-transformation to adapt to and change their situation. In these processes, Mary is used as an (ambiguous) role model.

\section{JOSEPHINE'S JOURNEY OF VIOLENCE}

Sometimes I wonder: how did I survive all this? I thank God and our Lady, she is my role model: a simple, humble woman.

Josephine (49 years), mother of seven children and grandmother of five, expresses her gratitude to God and Mary as she reflects on her life, which she perceives as a 'journey of violence'. Josephine originated from a small village near the town of Lae, married there and subsequently moved with her husband to Lae. There they lived until they separated and Josephine moved to Madang in 2001. When I met her in 2005, Josephine was working at the Archdiocesan HIV/AIDS office in Madang. Since 2004, Josephine has been giving advice about HIV/AIDS, organising prevention campaigns that are aimed at changing people's sexual behaviour and, thereby, their moral conduct.

When discussing the subject of sexual violence and the threat of HIV infection in Papua New Guinea, Josephine began to tell me her own story. My arrival in her office coincided with her efforts of trying to reconcile with the past, finding out who she is and, in particular, if she should speak out against the violence that has affected her life since 1973. Being an educated, fluent English speaking, mature and strong woman with a background of having occupied leading positions in religious organisations, such as the Catholic Women's Association (CWA) and the Legion of Mary, she feels herself to be oppressed by individual men, and, at a general level, by the male dominated society of Papua New Guinea and its male dominated institutions, including the Church.

Is it my right to speak the unknown that has been violating me? Speaking my rights as a Melanesian daughter, as a mother of seven children, a grandmother and as a separated wife? Or do I have to protect myself? Keep silent because of my patrilineal society in which I cannot speak out my rights because this [violence to women] is normal to everyone? (Interview with Josephine: Madang 2005)

Obviously, our encounter enabled her not only to tell her story and ventilate her grudges, but also to have an outsider acknowledge the suffering she experienced and still experiences. Josephine started her narration of her 'journey of violence' with a story about her daughter, who was the victim of a gang rape.

My daughter was working as a teacher in a remote area. On their way back their 
truck was looted and all the female teachers, including my daughter, were dragged out of the truck. The male teachers were trying to help them but there were too many raskols [roving band of criminals]. They pulled my daughter aside and she was raped. When she told me, I cried. At that time, my husband came home and found us crying. He started hitting me, beating me, saying it was my fault that my daughter was crying. My daughter then started crying because of me. I asked him to stop so I could take care of our daughter. He stopped and I took her to the hospital; we were so afraid of AIDS. She had a boyfriend and we did not know how he would react upon my daughter having been raped. Fortunately, the test was negative; no AIDS. Her father did not know what had happened to her. He just left us for 3 years. So, this is what we as women are facing! (Interview with Josephine: Madang 2005)

The narrative of her daughter's rape embodies Josephine's experiences as well as her reflection on the different forms of violence women might face. The violence addressed in Josephine's narrative is multiple (Kleinman 1997) and consists of 'acts of violence', as well as 'states of violence' (Brown 1987). Criminal violence (hold up and looting), sexual violence (in this case rape by strangers), domestic violence (physical beating and emotional abuse by the husband), and violation of health (risk of being infected with HIV) are all acts of violence. In Josephine's experience, these take place on the street and in the community, in domestic settings, at work and, as shown later, in institutions, such as the Church.

Josephine's experiences with the different acts of violence are not unique. As argued by Bradley (2001:2), 'the majority of adult women of Papua New Guinea have been physically assaulted by their husbands, forced to have sex with them, or have been raped or sexually assaulted by other men'. Statistics also reveal that domestic violence is the most dominant form of sexual violence. Surveys conducted in the mid 1980s showed that $67 \%$ of rural women, and $56 \%$ of urban women have been hit by their husbands (Toft 1985:14). ${ }^{2}$ In my own research among Catholic women in Port Moresby and Madang from August 2005 till February 2006, I found that 22 of the 42 female members of the Catholic Women's Association and the Legion of Mary whom I interviewed reported having experienced domestic violence.

Josephine's husband hitting her and accusing her of being responsible for her daughter's grief was not an isolated incident. It was part of a structural physical and emotional abuse that Josephine faced during her 27 years of marriage. As she described her relationship with her husband:

My husband and me were always fighting. When I was pregnant of my first daughter, he had another woman. He humiliated me, he hit me, and he abused me sexually. It was very painful, and I was very ashamed. I felt inhuman.... (Interview with Josephine: Madang 2006).

A census conducted in the 1980s reveals that marital fights are mainly the result of alcohol, money and jealousy, followed by problems with the children and violence by the husband (Conway and Mantovani 1990:121-122). Domestic violence was attributed to men's drinking, gambling and bad temper, and to women's behaviour, such as gossiping, going out alone, not doing their duties and talking to unknown members of the opposite sex (Conway and Mantovani 1990:127). In Josephine's case, many of the reasons given above resulted in the 'state of violence' between Josephine and her husband. In particular, jealousy and loss of control played an important part. Josephine, who at the time of the abuse was working for the Catholic Church in Lae, was blamed for committing adultery with one of her male colleagues. Josephine denied the allegations but her husband did not believe her and responded with violence. In turn, Josephine accused her husband of adultery, which led 
to scolding and aggressive acts. Moreover, Josephine's husband not only disapproved of her public conduct, but also of her private behaviour, which he argued was too flamboyant and not in line with his expectations.

Josephine's case, as well as others, shows that in general, violence against women occurs when 'men perceive they have lost control over women, when women are perceived by men to have breached certain expectations of conduct, or when there are underlying prior injuries within the family' (cf Banks 2000). In particular, continuing attitudes of male dominance (Kidu 2000:30) and gender based-hierarchies seem to fuel violence towards girls and women (Eves nd: 26).

This gender-based violence leads to another form of violence: the endangering of women's health. One of the major problems Papua New Guinea is facing today is the looming threat of an HIV/AIDS epidemic. Among the reasons for this crisis is, in addition to gender-based violence, increasing impoverishment, which in combination ensure a high vulnerability to the virus (Jenkins 1995: vii). Moreover, because women's health is often poor, women and girls in particular face a high risk of HIV infection (ibid). This risk is increased by the fact that women have hardly any means for protection against AIDS. While the government advocates the use of condoms, it appears that due to women's inability to negotiate for safe sex, many are unable to use them or "Just say "No"" (Hammar 1999: 151, 2007: 79). In addition, especially among Catholics, when it comes to contraception, there is a strong belief that condoms interfere with the plan of God, and in AIDS awareness, that condoms are actually spreading HIV as they encourage sexual promiscuity. Josephine, who works at the Archdiocesan HIV/AIDS office is of a similar opinion, urging her clientele to practise the calendar method or abstinence and faithfulness instead. Her own experiences, however, show that this might be difficult to achieve. Josephine's husband had unprotected sex with others while Josephine could not refuse him. So, it seems women, and especially Catholic women, are unable to protect themselves against being infected with HIV and other sexually transmitted diseases (STD) (see also Hammar 2007: 79). Moreover, once infected, women can find it difficult to obtain help because they are prevented from doing so (Hammar 1999: 150).

The different acts of violence endured by Josephine and other PNG women, result in, and are the result of, states of violence that effectively structure people's everyday lives (Schmidt and Schröder 2001:1). In Josephine's experience, the domestic violence she endured for 27 years was not only physical. The fact that she and her husband were always arguing is as much part of her perception of the violence that structured her everyday life as the physical abuse. In a similar way, the regular adultery of her husband and his disrespect towards her constituted Josephine's sense of having to endure a lifetime of violence. The effects of this violence on her children equally contributed to Josephine's sense of suffering. Josephine is convinced that the violence that was part of her married life resulted in her first daughter's sudden death. Moreover, she feels she herself is responsible for her daughter's death. This guilt results in an all-pervasive sense of suffering, which is, as argued by Kleinman (1997), a form of everyday violence. Women not only have to cope with violent acts, which are both physical and emotional assertions of power (Schmidt and Schröder 2001:1), but also with 'a state of violence'. Moreover, this personal 'state of violence' is confirmed and enhanced by media and official reports.

Almost every day, media reports inform Papua New Guineans, as well as the world, that Papua New Guinea is a violent society. In addition to violent burglaries and hold ups, sexual violence against women and girls seems to be endemic, and, according to some, even increasing. The regular front-page news coverage and the activities of both government and non-government organisations concerning the occurrence of sexual violence seem to have created a 'social panic' (Borrey 2000:105). Whether this panic is appropriate or not, as Borrey argues, the fact is that especially in Papua New Guinean towns, women live in a state of 'low level terror' (MacIntyre in Bradley 2001:2). 


\section{THE SETTING OF MADANG}

Although Madang is peaceful compared to the major towns of Papua New Guinea - Port Moresby, Lae and Mt. Hagen - in Madang too, 'acts of violence' constitute and are constituted by 'states of violence'. This has to do with, as I argue, the specific sociality of urban settings and a related fear of immorality.

Madang, the provincial capital of Madang Province, has grown into a small town of 28,547 inhabitants (NSO 2002) and is the only place in the region that provides work and various schooling opportunities. Consequently, Madang may be termed a melting pot as it is inhabited by people coming from all over Papua New Guinea (ibid) in order to seek education for their children, for work, or to enrol as students at the Divine Word University. Due to its opportunities, Madang attracts businesses and people coming from abroad, such as Asians who run almost all supermarkets, restaurants and fast-food shops in town. Moreover, Madang can be considered a transitional place, a place of travel.

Tourists frequently visit 'Beautiful Madang', spending their time at one of the many resorts, and every day Highlanders travel from Goroka to Madang to sell their string bags and garden produce on the local market. In addition, inhabitants of Madang regularly travel between their families' rural villages and the city. This mobility seems to construct the rural and the urban as an extension of one another. So, Madang can be seen as both a centralizing and a transitional place, embodying multiple connections. This setting clearly has an impact on the forms of sociality that exist in Madang, in particular with regard to family, gender and kinship relations.

As has been argued by Conway and Mantovani (1990:52) for married life in Papua New Guinean towns, such dynamic and multiple contexts result in 'new and distinctive Melanesian relations in urban families', as the nuclear family has replaced the extended family unit, characteristic of the rural areas, thereby enforcing both husband and wife to redefine their responsibilities and gender roles.

First of all, the urban wage structure has forced men and women to change their traditional work roles. Although an overwhelming degree of cultural variation exists within Papua New Guinea, some general remarks concerning the changing gender roles and related responsibilities can be made. In town, men are in general held responsible for providing an income for the family (Conway and Mantovani 1990:101), as there is limited female earning capacity in the formal town wage sector (Conway and Mantovani 1990:22). In rural areas, however, the whole family depends to a large extent on women's garden produce and their work. 'Although men are often responsible for some productive tasks such as clearing new lands, and might help with some of their wives' tasks [...], women are the primary subsistence gardeners' (cf Morley 1994: 36,38). In towns, women who do not have income from market produce, or from the formal economic sector, depend on the husband's fortnightly pay to feed and clothe their families. In some cases these new gender roles result in marital problems, as women have no access to their husbands' money, and, as a consequence, have no money to feed the family (Conway and Mantovani 1990:101).

Secondly, the urban environment challenges existing gender relations and gender roles. For example, women in town often have more freedom of movement, and as a consequence, have more opportunities to establish other relationships (Conway and Mantovani 1990:52). This might create jealousy, and men might get angry with their wives just for looking at other men, as several of my informants experienced and told me.

A related aspect is that women in towns may venture into domains that are linked with male success. Women's education and employment, especially when they take leadership positions, may cause jealousy and result in gender-based violence. As argued by Knauft (1997:241), the increased mobility of women and 'their interaction with the larger social universe can be threatening to emerging but uncertain notions of male prestige that are increasingly linked to success in these same contexts'. Josephine's case shows this par 
excellence. Occupying fairly high positions within the Catholic Church's offices in Lae and now Madang, Josephine has repeatedly experienced both physical and verbal harassments not only by her former husband, but also her male colleagues and current neighbours, who envy her for having a well-paid job and a car, while condemning her for living alone. Umberson et al. (2003:33) suggest that such violent behaviour of men in domestic settings is linked to the demonstration of their masculinity. A similar argument has also been ventured by Jenkins (2004), who argues that in patrilineal societies such as in PNG, 'idealized masculinity includes dominance over women, particularly in the public domain [..]' (cf 2004:12-13; see also Eves nd). Scholars such as Dorothy Counts (1990:242-243, 1992:7172), Josephides (1994:187) and Zimmer-Tamakoshi (1990) suggest that 'women's increasing status vis-à-vis men combined with changes in women's roles and rights may pose a threat to men, leading them to attempt to reassert their dominance, and as such their masculinity, through violence' (Morley 1994:43).

In addition to family and gender relations and notions of femininity and masculinity that need to be reworked, kinship relations equally change when moving to and living in an urban setting. Although people living in towns such as Madang often have to live without their relatives' help, there is nevertheless a lot of traffic between the 'urban' and the 'rural'. This transitional character of Madang becomes clearer when considering that women like Josephine regularly travel between Madang and their parents', and in married women's cases, their husbands' village, and that relatives from these villages regularly come to Madang and stay with their urban kin. As articulated by an emotional Josephine, this urbanrural kinship relation is not without burden. When she goes back to visit her village, she is confronted with her relatives' demands concerning the particular roles she is expected to perform. When her relatives visit Madang, she equally worries about their demands: 'When my wantoks [relatives] come to Madang, they all want my [financial] help. What do I do? I close the door, go on my knees and cry'. Obviously, not all urban-rural relationships are so stressed. For several women I spoke to, the absence of relatives in town offers new insecurities and dangers, and they regret having no relatives in town. According to Agnes, who works as a nurse in Madang:

In town, I am afraid for my children. Here we have got radio, television, violence. They might do bad things, swear. In the village, there is always wantok to look after them, but not in town. This is my big problem to Mary. She knows my worries (Interview with Agnes: Madang 2005)

The general fear of immorality, articulated by Agnes, not only encompasses bad influences from television, violence and swearing, it also entails the breaching of 'traditional' gender roles and gender conduct, scandals of corrupt government officials, criminality, and the looming threat of an HIV/AIDS epidemic (see also Barker 2007:13). Question is, how to deal with these anxieties and immoralities of town-life?

The official response to morally threatening issues such as gender-based violence and AIDS has been rather slow and mainly consists of poster campaigns, promoting the use of condoms and respect towards women. ${ }^{6}$ Likewise, organisations such as the Country Women's Organisation in Madang and the Madang Family and Sexual Violence Committee have launched poster campaigns against domestic and sexual violence by addressing men's lack of respect towards women. While the success of these campaigns is debatable (Eves nd: 55, 88-89; Hammar 2008), the impact of religious movements in addressing morally threatening issues such as violence and AIDS seems to be enormous (see for example Eves 2003, 2008; Hammar 2008). As already elucidated in Agnes' reflection, Marian devotion is among these movements, addressing personal and moral anxieties instigated by current socio-political problems. 


\section{Marian devotion in Madang}

In Madang, as in Papua New Guinea's other urban areas, the abundance of churches, evangelical rallies and the popularity of gospel music testifies to the popularity of Christianity and its pervasiveness in daily life. The majority of the people living in the urban areas of Madang Province are Catholic (35\%), followed by Evangelical Lutheran, Pentecostals and Seventh Day Adventists (NSO 2002). The predominance of Catholicism in Madang Province is also visible in Madang town, which is the Papua New Guinean cradle of 'the Legion of Mary'. This lay Catholic organisation was founded in Dublin, Ireland in 1921. Spread over the world, its members are giving Glory to God 'through the holiness of its members developed by prayer and active co-operation in Mary's and the Church's work'.

Mary 'The Immaculate Conception' is the legion's worldwide leader. As a legionary, members are expected to submit to Mary. 'Completely submitted to Mary, the legionary distrusts the promptings of his own inclinations and in all things listens intently for the whisperings of grace'(Moran and Connell 1993, 30). In fact, '[...] the giver places himself in a condition equivalent to that of a slave possessing nothing of his own, and wholly dependent on, and utterly at the disposal of Mary' (Moran and Connell 1993:37). In addition, based upon Genesis 3:15, the legion perceives itself as Mary's warriors against sin, turning to Mary's enmity with the devil as a 'source of confidence and strength in its warfare with sin' (Moran and Connell 1993:20). The legion is thus perceived of as an army, which 'throws itself in the warfare of Christ' in which its members submit themselves 'to His glorious commands'. Being both slave and warrior is actually seen to empower the legionaries. As the handbook states: 'The imitation of Mary's humility is both the root and the instrument of legionary action' (Moran and Connell 1993:27). As will be seen later, this humility is a key-value around which legionary as well as other Catholic women shape their identities.

The basic unit of the Legion of Mary is called a praesidium. The secretary and president of each praesidium have to report to their council, their curia, who in turn have to report to their regia, which falls under a consilium. In Papua New Guinea there are two regias, one on the mainland of PNG and one in the islands of PNG. These regia work with the consilium in Ireland. The regia on the mainland of Papua New Guinea has its headquarters in Madang and looks after 54 curia, making Madang the centre of all legion activities in the country.

Each week, both male and female members of the Legion of Mary in Madang gather for a praesidium meeting, intermingling prayer with reports and discussion. In addition, each member is assigned work to be performed during the week, which is done in co-operation with another member. Mostly, this implies visiting sick people in Madang hospital, but sometimes legionaries also visit people in jail or others in need of spiritual help. For the women I interviewed, the weekly legionary meetings and assigned works are a constitutive part of a Catholic network that comprises, in addition to the legionary membership and related duties, Sunday mass and subsequent meeting with legionary members and other Catholics, weekly evening prayer groups, visiting evening masses in the Madang area, and occasional Church work, such as fundraising, cooking and cleaning. In fact, it seems that this Catholic network provides an alternative to the wantok system in the village, enabling legionaries and other Catholics to create and maintain social ties based upon mutual faith. For the legionaries as well as many other Catholics in Madang, Father Ernest Golly is the pivot of their extended Catholic family.

Since the late 1970s Father Golly has been the legion's national director. In addition to translating the legion's handbook, he has published several dozen pamphlets on Marian devotion. Besides being the national director, he is also the spiritual director of the mainland regia and parish priest of Jomba parish in Madang. In these functions, he controls to a large extent the practices of the Legion of Mary in Madang and also in PNG mainland, and how Catholicism, and in particular Marian devotion, is practised in Jomba parish and 
beyond. ${ }^{8}$ In Fr. Golly's view, devotion to Mary is an essential part of Catholicism ánd Christianity.

In the Catholic Church, we are clear about it. Real Catholics, those who accept the real faith that Jesus brought us, agree. According to the plan of God, Mary has a special role. Starting in paradise. God told that He would create a new Eve who would be the enemy of Satan (Genesis 3:15). Her offspring is God, Jesus. This woman and her offspring will crush the head of the devil, of Satan. Missionaries were teaching this. Especially in the Legion of Mary: we are the army of Mary to crush the head of Satan. Real Catholics will not neglect the devotion to Mary. Through history you can see that the devil will do everything to stop devotion to Mary. The Catholic Church loves Mary, the mother of Jesus. True Catholics will not give up devotion to Mary. She is the plan of God. This is what missionaries have been teaching here in Papua New Guinea. If priests, Christians call against Mary, they are against God! (Interview with Fr Golly, Yomba Parish 25/08/2005)

Father Golly's strong, fire and brimstone theology is very much appreciated and at the same time feared by most of the legionaries and his parish members. Golly offers them a clear and straight path to follow, those who go astray are in the devil's hands. This rhetoric is especially clear when Golly addresses the issue of HIV/AIDS.

God does not allow us to use condoms. We are not animals! People should use the calendar method. This is the way of God. Condoms are the Devil's work! The only country where AIDS is decreasing is Uganda. They took the way of the Lord! (Interview with Fr Golly: Jomba Parish 25/08/2005)

In Fr. Golly's view, a strong belief in God and devotion to Mary can bring redemption and prevent people from falling prey to Satan. In fact, he advocates the use of Mary as a role model in order to solve moral and social problems, including HIV/AIDS. This use of Mary as a role-model to combat morally troubling issues is not only propagated by Fr. Golly. For example, in the Post Courier (December 29, 2004) medical doctor Thomas Vinit (Madang hospital) argues: 'Let us use good models that portray chastity and purity, such as the devotion of the Virgin Mary' in order to address the root of the HIV/AIDS problem in Papua New Guinea, which are 'moral and socio-economical problems'. faith in God is sufficient to combat HIV/AIDS and prevent infection is widespread among Christians in PNG (see amongst others Eves 2008), also among the Catholic women I interviewed. For example, Josephine is convinced that God protected her and her raped daughter from being infected with HIV. Moreover, this conviction is also instrumental in how women like Josephine, deal and cope with domestic violence. Confronted with such dilemmas as divorce in an environment where this is seen as sinful, these Catholic women seek spiritual guidance: finding solace in prayers directed to Mary and gaining strength by using Mary as their role model.

\section{THE POWER OF MARY: COPING WITH DOMESTIC VIOLENCE}

Just like Josephine, the Catholic women I interviewed pray to God and, in particular, to Mary in order to cope with their abusive partners or relatives. By praying and asking for divine intervention, they place their lives in the hand of God and 'Mama Maria'. By submitting to God, trying to accept their situation as being God's will and plan, women often gain the necessary strength to keep going on, that is: to stay with their husbands. The idea of suffering, of having to face this violence as part of their penitence in order to, eventually, 
receive holiness and redemption, equally strengthens women to stay in an abusive situation. Moreover, the conviction is that if you show patience and pray to Mary, those who backslide and commit sin will change their behaviour. This belief is expressed through the narration of particular experiences. These 'ideal' narratives are centred on women's devotion and faith. The following narrative is from Sophia (49 years, Legion of Mary since 1997. From Manus Island, living in Madang):

My husband left his faith and started drinking. I think it was due to his promotion. He became very proud, and he spent all his money, going around with other women. I prayed to Mary, put all this in my intentions to her. One day, I asked him for some money to give to the Church, he said: "olgeta pinis"[it is all finished]. I told him we had no money. I started to cry and the kids cried and then he realised he was wrong. He put his hands on the bible, the Lady was there, and he promised never to waste money again. He looked at me and I said: It is now with the Lord".

For 20 years he stayed well. Then, he got another job promotion. He owned a car and he got tempted again. I told him: "You have made a promise not to touch beer!" But he was in big trouble now, he was taken by Satan. He tried to bash me, tried to get a second wife. But I said "no!" I came to see father Golly. He told me he would help me. He said it would take me time to forgive.

Father Golly told me: "you pray the rosary. Mother Maria will help you". And, all of a sudden, my husband turned around again and he made his second promise. My family had told me: "Just let him go!" But I said: "no, I will forgive him. The Lord forgives so I must do the same". I did not want to be left alone, deserted with my children running around. So I stayed and I trusted God and Mary. Mary em pawa [Mary is power]. Mary helped me through the crisis. Now, my husband is committing himself. Every evening, we have the rosaries before we go to bed. This helps us. He is retired now and Mama? She gives us gutpela tingting [good things to think about].

Sophia's narrative confirms the existing ideal: 'pray hard enough and your husband will turn around'. If this does not happen, the consensus is that women have not prayed hard enough. Acording to Irmgard (member Legion of Mary, Madang):

Women should pray harder and more. Perhaps they are not praying to Mary, or they are not praying with all their intentions. If a woman prays hard enough, her husband will go straight again.

Sophia's exemplary narrative and Irmgard's reflection reveal how women's prayer, faith, and patience will heal their husbands and, as such, their marriage. In fact, domestic harmony is believed to be achieved by using Mary as a role model to transform their husbands by changing themselves.

\section{Mimicking Mary: the power of self-transformation}

Mary serving as a role-model for, in particular, women is not restricted to Madang or Papua New Guinea. All over the world, Mary's virtues of humility, obedience and faith are appropriated by women and inscribed on women's bodies. However, especially among legionary members, this use of Mary as an example, as a role-model whose virtues must be aspired to, is propagated. As stated in the handbook of the Legion of Mary: 
The Legion of Mary in particular aspires after Mary's profound Humility, her perfect obedience, her angelical sweetness, her continual prayer, her universal mortification, her altogether spotless purity, her heroic patience, her heavenly wisdom, her self-sacrificing courageous love of God, and above all Her faith. (Moran and Connell 1993:12)

For legionaries like Josephine, Mary as a role model inscribes them with qualities such as humility, patience, faith and obedience. Josephine affirms:

Mary is a model to me: "Pasin bilong em em daun passin" [her virtue is humility]. Understanding and following Mary, brought understanding about my own self. Now, I believe in humility and the truth. I find peace in not making others angry, but helping them instead.

While interviewing other female members of the Legion of Mary, I encountered similar expressions. Moreover, those who mimicked Mary's virtues best were held in high regard among the other legionaries, thereby encouraging each other to be like Mary. This aspiration to mimic Mary was also expressed by female members of the Catholic Women's Association (CWA).

What is striking in women's narratives and their aspiration to be like Mary is the emphasis on self-transformation. As expressed by Stella (CWA-member Madang, 27 years), 'Maria gave insight into my bad habits and I try to change them'. Likewise, according to Josephine, Mary's qualities as a humble woman showed her how she had failed in her own marriage. By changing herself, changing her own anger into humility, Josephine did, alas, not change her husband, but she received peace and acceptance of her situation as it is now. For many of the other abused women I spoke to, however, this emphasis on self-transformation is the only way to change their situation, and in particular, their husbands.

Faced with domestic violence or other problems, the most effective way to achieve results is to focus on what can be changed: oneself. To scrutinise oneself and to work and turn oneself into a good Christian wife, is for most women the most accessible way to change their situation. This means that women actually attribute power and agency to themselves. As argued by Griffith (1997:166) in describing published narratives of Aglow women in the US, 'women centre their narratives on their own capacity to initiate personal healing and cultivate domestic harmony'. This personal power is, according to Griffith, encoded in a 'doctrine of submission'.

In women's narratives described by Griffith (1997:166), 'good results will follow a wife's willing acquiescence: once women's attitudes are transformed and they accept their submissive roles, their husbands also become happier and more benevolent'. Such a doctrine of submission is also visible in Catholic women's narratives, wherein submission is not only to Mary and God, but also to one's husband. As Mary, president of the Legion of Mary in Madang, describes it: 'Mary is our role model. She is obedient to God. So we submit to our men, they are the head of the family.' Veronica (member of the Legion of Mary, Madang) equally stresses Mary's role in providing her with a good example of being a good Christian woman who submits to both God and her husband: 'I imitate Mary's humility, Her faith, praying, sacrifices, obedience. Obedience to my husband and towards religious duties.'

Imitating Mary not only involves changing women's attitudes. It involves the transformation of one's identity and one's self. In fact, the emphasis on self-conversion towards the image of Mary actually calls for the submission and suppression of the self. As stated in the Handbook of the Legion of Mary: 'The legionary, in turning towards Mary, must necessarily turn away from self' (Moran and Connell 1993:30). The 'humble Virgin's heel' does not only crush Satan, but crushes also 'the serpent of self with its many heads'. These are heads of self-exaltion, of self-seeking, of self sufficiency, of self-conceit, of self-love, of self-satis- 
faction, of self-advancement and of self-will (ibid). This Christian rhetoric that calls for the turning away of the self, thereby also places emphasis on the self.

As argued by Robbins (2005), Christianity, in contrast to Melanesian notions of personhood, focuses on the subject, on the self. More precisely, 'Christianity forces oneself to identify with one's own inferiority, one's sinful nature'(Robbins 2005:46-47). It teaches people to look inward, to alter their notions of subjectivity as something to be regulated (ibid). Focus is thus on the subject, on the formation of self. This is also noticed by Richard Eves in his study on modernity, morality and illness among the Lelet people in New Ireland. By converting to Christianity, Lelet converts 'create a new self, a self-refashioning' in which they seek to cultivate a new Christian way of being (Eves 2005:28). The women I spoke to in Madang engage in similar processes of self-refashioning. By internalising and re-enacting Christian values through the image of Mary, focus is on self-discipline (see also Robbins 2005:51). Women are encouraged to monitor their behaviour, prevent cursing and arguing with their husbands, be patient and obedient. In Foucault's terms, women thus put themselves under 'self-surveillance' (Foucault 1997). Self-surveillance is usually understood as 'the attention one pays to one's behaviour when facing the actuality or virtuality of an immediate or mediated observation by others whose opinion he or she deems as relevant' (Vaz and Bruno 2003:273). In this case, one of the main constituents of women's behaviour is Mary and her inescapable, omni presence.

So Mary becomes a powerful icon around which women rework their identities and transform themselves into ideal Christian women through self-surveillance. In Madang, the adhered to doctrine of religious and domestic submission is empowered by Christian rhetoric, which demands obedience and, especially, submission from the wife, both in her relationship towards God and towards her husband. These values are propagated through books concerning Mary (for example Hahn 2001), which are extremely popular among Marian devotees, and Christian booklets that are published and distributed in Papua New Guinea (for example Fountain 1984; Malins 1987; Sala 1999). Moreover, these values are part of the rhetoric and advice given by legion members as well as by its spiritual director, Fr. Golly. As narrated by Josephine:

I was told to pray, pray. My spiritual director [Fr Golly] told me to find my weakness and perform. He told me: "You go back to your husband! I cried. I cried and I prayed, I was so scared to go back. But I went back, and...I was again abused. I went back to Father Golly and I told him that I valued my life, "who is going to take care of my children?" But he was looking at my marriage, not at my own safety.

In 1991, for 6 months, I did not give myself to my husband. Father Golly told me to break my heart of stone. And I prayed to do this and I did it, but without love, to satisfy my husband.

Griffith (1997) argues that personal power is encoded in women's submission as this enables them to change their situation by changing themselves. However, Griffith fails to provide insight into the fact that women's reworking of their identity is actually a very difficult and painful process. As narrated by Josephine, her efforts at being an ideal Christian woman were painful and the price she paid high. Josephine's experiences exemplify that self-surveillance implies internalising dominant discourses since these contribute to the construction of a coherent, Christian, identity. At the same time, Josephine is struggling with this discourse and its internalisations, as they collide with her own well-being.

\section{COLLIDING VALUES AND IDENTITIES}

Josephine was repeatedly advised to stay with her husband, but, in 2001 after 27 years of marriage, she decided to leave her husband in Lae and went to Madang. 
I stayed with him for 27 years. It does not mean I hate my husband; I waited for him to change. The thing that kept me going was that I had married him. He had to learn, we had to work it out. Patience is very good, you have to give it time. I waited for 27 years for him to realise his responsibilities and his duties. Also, I was very worried about my parents, I did not want to embarrass them. Moreover, I had married in Church and I did not want to break our sacrament.

Our suffering affected the children, so I kept quiet. Eventually, I could not cope with the reality of living with him anymore. I could no longer pretend to be someone else, to wear this mask of happiness. [...] I did not want to die, not to be raped within my marriage. I told my husband: "We have to stay apart". [...] In 2001, we separated to see what we could build up for ourselves. I feel I have failed in keeping my marriage together. Is it my fault?

Josephine's experiences exemplify the tensions and dilemmas that exist for women in dealing with domestic violence. Patience and faith, as well as the importance of marriage as a sacrament seem to collide with Josephine's own well-being. Also, due to Josephine's work, people expected her to save her marriage and at the same time stand up for herself. But although she was highly regarded in her positions in the Catholic Women's Association and the Legion of Mary, she could not speak out against others and her husband. The only way she could stand up for herself was by leaving her husband and making a life of her own, meaning she had failed in keeping her marriage together, that she had somehow failed in being a good Christian woman.

As with several other women I interviewed, Josephine is actually struggling and negotiating between self-preservation, Christian and 'traditional' values and morality, as well as with 'modernity' in which women are encouraged to speak out and make their own decisions. This dilemma and the apparent opposition between categories belonging to different cultural logics is embodied in Josephine's reflection:

We are still struggling, especially in the rural areas, that women have equal rights, especially in decision-making. We should be in the government to show them how we can improve Papua New Guinea. Women should have the courage to speak up for their rights.

In the village, once women are married, their responsibilities are to feed the children, go to the garden, cook etc. In town, women get confused: where do I stand? Some mothers go to work if the husband is also working. In some cases, the babysitter does the work, in others the woman does all the housekeeping as well. My daughter's husband is a teacher, just like her. But I see my daughter doing all the shopping. I ask her: "Do you share any responsibilities? If your husband is not helping you will not last long, you have to talk about it!" Husband and wife have to understand and respect each-others interests and talk about it.

For those women who have marital problems: "Identify the cause of the problems". If it is abuse, they need counselling and try to improve their lives. When they cannot cope anymore, I will not tell them to separate, but they need to help themselves with patience and humbleness. You have to stand up and fight for your rights, not with pride but with humbleness. I never talked about my husband's ill behaviour to others. I think women should talk about it, but they should be careful and think about confidentiality as people might gossip and the husband might hear it. My mother used to say: When you are talking about your husband, you are talking about yourself.

I also realised that sometimes we women are pitied because we are bossing over our husbands. Especially working mothers, they sometimes abuse their husbands. So that is when a couple needs counselling. Communication is very important. 
Otherwise, infidelity will come out of it. When the husband does not receive what he wants and expects, he will be attracted to other women who do listen to him and thank him.

Josephine's reflection reveals her inclination towards 'modernity', which grants women and men equal rights and opportunities, and which encourages women to speak out for themselves. However, when she turns to her role as a co-ordinator in the Diocese's family life office, she resorts to Christian values. She will not advise people to divorce, as Christian marriage is a sacred union established before the eyes of God. Instead, she argues that troubled wives have to fight for their marriage, meaning: they have to work hard and show humility. As such, women should not gossip or complain to others about their husbands' failures, as these, as Josephine was taught, are your own failures too. Moreover, she does not agree with women bossing over their husbands, as men are the head of the family. Finally, she warns that when women do not take good care of their husbands and fail to obey them, they will be prone to look for other women and commit adultery. In short, Josephine resorts to values that seem to belong to different cultural logics in order to address women's roles as mothers and, especially, as wives. The question is, to what extent are the different categories of values compatible?

It seems that 'traditional' and 'Christian' values confirm and complement each other resulting in a strong doctrine of submission that calls for particular gendered behaviour in which the self is submitted. This behaviour is founded in 'traditional' gender roles in many areas in Papua New Guinea, as also experienced by Josephine during her marriage and when temporarily returning to her village after the divorce.

First my brother: I had to submit to him with regard to ownership of land. Then my husband, to whom I had to submit regarding family roles, at the same time accepting his abuse. As an educated woman I still cannot speak out in the village. I have to submit myself, go down with the other women. Do I have to accept all this, or let it go? (Interview with Josephine: Madang 2006)

The 'traditional' gender roles as experienced by Josephine, in general prevent women from speaking up against their brothers, fathers, and husbands, and require them to be obedient, and to perceive men as leaders and as decision makers (see also Eves nd:26; Hermkens 2005:56-58). The Christian rhetoric of obedience, forgiveness and patience equally forces women to submit to the head of their families, either their father or their husband. In contrast, it seems that the 'modernity' aspired to by Josephine and others, which is profoundly associated with the self (see also Barker 2007:8-10), does not fall into previously known categories of gender roles and, as such, gender identity. As Josephine painstakingly asks herself: "Who am I, what is my identity? Where do I stand with my Christian values?" This struggle of Josephine reflects the struggle with the self in 'modern' contexts such as Madang, where people are living in between worlds with different yet similar logics.

\section{THE POWER OF MARY: RE-ENACTING NORMATIVE VIOLENCE}

This article has addressed the place of Mary for a particular group of urban Catholic women in their negotiation with various forms of violence. As shown, women like Josephine not only have to cope with violent acts, but also with 'a state of violence'. This state of violence is linked to the dynamics of the urban context in which morally troubling issues, such as gang violence, criminality, gender violence, breaching of gender roles, the absence or presence of wantok, and the threat of HIV/AIDS affect people's lives.

In fact, the urban context shapes particular forms of sociality, self-understandings and religious orientations. The new and distinctive Melanesian relations in urban families call 
for a re-definition of gender relations, gender roles and gendered selves, and a re-composition of social relations and sociality. Much as Reed (2003:82) has argued for those living in Bomana prison, Madang can equally be considered as a place of social reconstitution. People have to create new forms of sociality. It seems that Christianity plays a crucial part in this process of 'modernization', as people are trying to constitute a new sociality through Christian moral and religious networks. Living one's faith, and in particular Marian devotion, is seen to be an important strategy to deal with the complex urban setting, including acts and states of violence. Religion can thus be perceived as 'one of -if not the -primary media' through which people make and remake their social landscapes (Orsi 1997:10).

At the same time, it seems that Christianity is also in conflict with the modernity aspired by women like Josephine. They are caught up between different values and expectations, meaning they have to constantly negotiate between the different roles they are expected to play and perform. This balancing and negotiating of one's identity is not always easy. As Josephine sighs: 'I guess all these problems are all part of our growth or development. But it is also very confusing. We have the traditional versus modernity. But which way to go?'

Confronted with the dilemmas of establishing one's gender roles in the dynamics of the urban context, the women I interviewed looked for spiritual guidance, seeking solace in prayers directed in particular to Mary. Mary not only offers women solace and help, She appears to empower women to endure their suffering, and, after Mary's example, to give confidence in the process of transforming oneself into good and strong Christian wives. The women I interviewed see this transformation as empowerment, of being able to change themselves, and, eventually, their situation and, in particular, their husbands.

However, when seen in the light of Foucault's notion of self-surveillance, this empowerment becomes feeble. As shown, women's self-surveillance is constituted by gender relations, the religious community, such as the members of the Legion of Mary and Church clergy like Fr. Golly, but also by, and perhaps even more importantly, the Virgin Mary. Mary's submissive image coincides with pre-existing gender relations and gender hierarchies, in which women's roles are constituted as being submissive to their husbands with emphasis on their roles as caretakers of the families, as mothers. As already noted, the Church's teachings on Mary 'reflect and express the ideology of the patriarchal feminine' (Ruether 1993:149). The virtues ascribed to Mary in the teachings of the Church and the Legion of Mary, such as silence, obedience and modesty, constitute the very quintessence of passive, female submission (McLauglin 1974). The advice given by Fr. Golly to abused women, urging them to stay in an abusive relationship, be patient and show forgiveness towards those who abuse them, is equally part of this disciplinary power. In fact, one can argue that Marian devotion and its focus on self-surveillance is actually a form of normative violence, or a state of violence, as it submits women to a violent doctrine of submission. This doctrine of submission reduces women to, in Foucault's terms, docile and subjected bodies and thus seems to deny the possibility of resistance and agency. Josephine's journey of violence shows how she struggles to resist its disciplinary power - trying to stand up for herself, make her own decisions, follow her own career, and be a leader - while simultaneously adhering to it.

However, when looking at women's narratives and experiences, Mary also seems to provide an escape. Mary is held up to women as a model and is appropriated by women as a model. But this model is appropriated and internalised in ways that not always concur with the Church's teachings, or notions of the patriarchal feminine. Women like Josephine not only admire Mary's virtues of patience and modesty, they also see Mary as a strong woman, as a leader. Josephine, who has ambitions of being and becoming a leader herself, explains: 'Mary is a big female leader. When we women look at her, we can see our responsibilities in our family and in our communities'.

So, Mary's role is even more ambiguous than is evident in her paradoxical role of helping women to stop violence and, on the other hand, of facilitating power which con- 
strains women. In fact Mary's submissive image can transform into that of a strong and powerful woman. This particular image provides women not only with an example of how to be a good Christian mother and wife, but also that it is possible to be a strong woman leader. This role of Mary coincides with the fact that religious women's groups are in the foreground of changing things in Papua New Guinea, including gender relations (DicksonWaiko 1999, 2003; Lee 1985; Sepoe 2000). Mary's role as a strong woman thus also enables her followers like Josephine to appropriate leadership positions and endure the struggle that goes with such positions and aspirations in the context of contemporary Papua New Guinean society.

\section{ACKNOWLEDGEMENTS}

I am indebted to all who have accommodated and assisted me with my research in Papua New Guinea. Special thanks to Father Joe Forstner, the members of the Legion of Mary, and the Catholic Women's Association for assisting me with my research in Madang. Thanks also to Father Jurgen Ommerborn, Philip Gibbs, Richard Eves, John Barker, Lawrence Hammar and the anonymous reviewer of Oceania for providing useful comments on earlier versions of the article. Special thanks to all participants of the ASAO session 'Engendering Violence' for their comments and suggestions. I thank the 'Netherlands Organization for Scientific Research' (NWO) for funding and the research-programme 'The Power of Pilgrimage' at the Radboud University Nijmegen, Netherlands for institutional support.

\section{NOTES}

1. By using 'traditional' and 'modern' I am not implying a rigid distinction between these two concepts, nor am I implying that the rural is per definition 'traditional' and the urban 'modern'. Moreover, as already argued by Kahn (2001) and others, there are multiple modernities. John Barker, in a lecture given at a conference in Nijmegen on the $31^{\text {st }}$ of June 2005, argued that Christianity may in fact be a traditional sort of modernity, thereby emphasizing the slippery as well as dynamic nature of the concepts of tradition, modernity, as well of Christianity in PNG (see also Barker 2007).

2. The PNG Law Reform Commission conducted research on domestic violence between 1982 and 1992. The final report (1992) showed that $70 \%$ of all women in Papua New Guinea have been beaten by their husbands.

3. From August 2005 until February 2006 I did fieldwork in, amongst others, Port Moresby and Madang concerning Marian devotion and domestic violence. In addition to five interviews with Christian women who are not affiliated with particular religious groups, interviews were conducted with women belonging to the Catholic Women's Organisation (CWA) in Madang (19 women), and with women belonging to the Legion of Mary in Madang (10 women and three men) and Port Moresby (13 women). Of the 19 CWA women, 16 reported to have been beaten by their husbands, while among the Legion of Mary members in Madang and Moresby six women (three in Madang and three in Port Moresby) had faced domestic violence. The women I interviewed belong to different tribal backgrounds. Moreover, they belong to different socio-economic strata, although none of them lives in the so-called squatter settlements. The majority can be labelled as middleclass with a few women belonging to lower- and one woman to the upper-class.

4. Various studies have tried to analyse the 'culture of violence' in Papua New Guinea (Bradley 1994, 2001; Dinnen 1997; Dinnen and Ley 2000; Jenkins 1995; Kidu 2000; Toft 1985; Zimmer-Tamakoshi 1990, 1997, 2004). In addition to existing gender hierarchies and male dominance, factors that have been addressed in relation to sexual violence are: economic impoverishment and increasing criminality, changing gender relations, as well as a decline of morality, especially in urban settings.

5. PNG is on the brink of a serious HIV/AIDS epidemic. It was estimated that in 2004, over 15,000 people (total population of PNG is circa 5 million) were living with HIV/AIDS in PNG (http://www.oxfam.org.au/world/pacific/png/; last visited July 2005).

6. To address gender-based violence, the PNG government has conducted large-scale research through the Law Reform Commission in the 1980s (Toft 1985a, 1985, 1986; Toft and Bonnel 1985). Despite these reports, however, the government has been slow to respond and take adequate measures (Bradley 2001). Deploying huge billboards, advertisements and posters, the official message is clear: Real men do not harm women and girls, and, if men and women want to have sex, they should use condoms.

7. http://www.legion-of-mary.ie/; last visited May 2006.

8. Although Fr Golly has a huge influence among Catholics (both legionaries and non-legionary members) in Madang, he is certainly not representative of all Catholic priests in Papua New Guinea. In Madang alone, there are several Church officials who do not concur with Fr. Golly's point of view and how he counsels his 
legionary and Parish members. However, he faces little or no interference from the Catholic community and his superiors.

9. Dr. Vinit, while strongly opposing condoms, is now head of the Lifestyle Diseases Division of the National Department of Health (Hammar 2007:75)

\section{REFERENCES}

BANKS, C. 2000. Contextualising sexual violence: Rape and carnal knowledge in Papua New Guinea. In Reflections of Violence in Melanesia edited by S. Dinnen and A. Ley, pp. 83-104. Australia: Hawkins Press/ Asia Pacific Press.

BARKER, J. 1990. Introduction: Ethnographic perspectives on Christianity in Oceanic societies. In Christianity in Oceania: Ethnographic perspectives. Edited by John Barker. ASAO monographs 12, Lanham, 1-12.

1992. Christianity in Western Melanesian Ethnography. In History and tradition in Melanesian Anthropology. Edited by James Carrier. Studies in Melanesian Anthropology 10. Berkeley, 144-173.

2007. Introduction: The Anthropological Study of Morality in Melanesia. In: The Anthropology of Morality in Melanesia and Beyond. Edited by John Barker. England, USA: Ashgate, 1-21.

BORREY, A. 2000. Sexual violence in perspective: the case of Papua New Guinea. In Reflections of Violence in Melanesia edited by S. Dinnen and A. Ley, pp.105-118. Australia: Hawkins Press/ Asia Pacific Press.

BRADLEY, C. 1994. Why male violence against women. Methodological and personal perspectives. London: Sage publications.

2001. Family and sexual violence in Papua New Guinea: an integrated long-term strategy. Report to the family action committee of the consultative implementation and monitoring council. Waigani: Institute of national affairs.

BROWN, R. MCAFEE. 1987. Religion and violence. Philadelphia: Westminster Press.

CONWAY, J. and E. MANTOVANI. 1990. Marriage in Melanesia: a sociological perspective. Point series 15. Goroka: The Melanesian Institute.

COUNTS, D. AYERS. 1990. Domestic violence in Oceania: Conclusion. Pacific Studies 13 (3):225-254.

1992. 'All Men Do It': Wife-beating in Kaliai, Papua New Guinea. In Sanctions and Sanctuary: Cultural Perspectives on the Beating of Wives edited by Dorothy Ayers Counts, Judith K. Brown and Jacquelyn C. Campbell, pp.63-76. Boulder and Oxford: Westview Press

DICKSON-WAIKO, A. 1999. Civil society and development, non-government organisations and churches. Development Bulletin 50 (October):44-46.

2003. The missing rib: Mobilizing church women for change in Papua New Guinea. Oceania 74 (2):98-110.

DINNEN, S. 1997. Law, order and state in Papua New Guinea. Discussion paper 1, State Governance in Melanesia, RSPAS ANU, Canberra.

DINNEN, S. and A. LEY. 2000 (eds). Reflections on Violence in Melanesia. Australia: Hawkins /Asia Pacific Press.

EVES, R. 2003. Aids and Apocalypticism: Interpretations of the epidemic from Papua New Guinea. Culture, Health \& Sexuality 5 (3):249-264.

2005. In God's Hands': Modernity, morality and illness in a Melanesian Society, paper prepared for Old and New Religions, Hybridisation, and the Challenge of Modernity at the Australian Anthropological Society (AAS) Annual Conference, Adelaide, September 2005.

2008. Moral Reform and Miraculous Cures: Christian Healing and AIDS in New Ireland, Papua New Guinea. In: Making sense of AIDS. Culture, Sexuality and Power in Melanesia. Edited by Leslie Butt and Richard Eves, pp.303-325. Hawaii: University of Hawaii Press.

Nd. Exploring the role of men and masculinities in Papua New Guinea in the $21^{\text {st }}$ century. How to address violence in ways that generate empowerment for both men and women. Report for Caritas Australia.

FOUCAUlT, M. 1997. The subject and power. In M. Foucault The Essential Works 1954-1984, Vol. III. Power, edited by J. Faubion. New York: The New Press, 326-348.

FOUNTAIN, O. C. 1984. Marriage the Melanesian way. Wewak: Christian books Melanesia Inc.

GRIFFITH, R. M. 1997. Submissive wives, wounded daughters and female soldiers: prayer and Christian womanhood in women's Aglow fellowship. In Lived religion in America. Toward a history of practice edited by David Hall, pp. 160-195. New Jersey: Princeton University Press.

GODDARD, M. and D. VAN HEEKEREN 2003. United and divided: Christianity, radition and identity in two South Coast Papua New Guinean villages. The Australian Journal of Anthropology, vol. 14 (2): 144-159.

HAHN, S. 2001. Hail Holy Queen. New York: Doubleday.

HAMMAR, L. 1999. To be Young, Female, and "Normal": The Health Risks of Absent Sexual Citizenship. Journal of Medical Humanities 20(2):135-154.

2007. Epilogue: Homegrown in PNG - Rural responses to HIV and AIDS. Oceania 77(1):72-94.

2008. Foreign Objects and Cognitive Dissonance: the strange waters of anti-condom discourse. In: Making sense of AIDS. Culture, Sexuality and Power in Melanesia. Edited by Leslie Butt and Richard Eves. Hawaii: University of Hawaii Press.

HERMKENS, A. 2005. Engendering Objects: Barkcloth and the Dynamics of Identity in Papua New Guinea. Nijmegen: Radboud University.

2007a. The Power of Mary in Papua New Guinea. Anthropology Today 23(2):4-8.

2007b. Religion in war and peace: Unravelling Mary's intervention in the Bougainville crisis. Culture and 
Religion 8(3): 271-289.

JEBENS, H. 2005. Pathways to heaven: Contesting mainline and fundamentalist Christianity in Papua New Guinea. Oxford and New York: Berghahn.

JENKINS, C. 1995. Women and the risk of AIDS: A study of Sexual and reproductive knowledge and behaviour in Papua New Guinea. Women and AIDS Research Program. Research Report Series 10. Washington: USAID

2004. Male Sexuality, Diversity and Culture: Implications for HIV Prevention and Care. Report for UNAIDS

JOSEPHIDES, L. 1994. Gendered violence in a changing society the case of urban Papua New Guinea. Journal de la Société des Océanistes (99): 187-196.

KAHN, J. 2001. Anthropology and Modernity. Current Anthropology 42: 651-680.

KIDU, C. 2000. Reflections on change, ethnicity and conflict: Family and ethnic violence in Papua New Guinea. Development Bulletin 59 (November): 29-33.

KLEINMAN, A. 1997. The violences of everyday life. The multiple forms and dynamics of social violence. In Violence and subjectivity, edited by Veena Das, Arthur Kleinman, Mamphela Ramphele and Pamela Reynolds, pp. 226-241. Berkeley: University of California Press.

KNAUFT, B. 1997. Gender identity, political economy and modernity in Melanesia and Amazonia. The Journal of the Royal anthropological institute 3 (2):233-259.

LEE, W. 1985. Women's groups in Papua New Guinea: Shedding the legacy of drop scones and embroidered pillowcases. Community development journal 20 (3):222-235.

MALINS, I. 1987. Christian marriage and family life. Wewak: Christian books Melanesia Inc.

MCLAUGHLIN, K. E. 1974. Equality of Souls, Inequality of Sexes: Woman in Medieval Theology. In Religion and Sexism. Images of Woman in the Jewish and Christian Traditions, edited by R.R. Ruether, pp. 213266. New York: Simon and Schuster.

MORAN, J. and D. CONNELL. 1993 (editors). The official handbook of the Legion of Mary. Dublin: Concilium Legionis Mariae.

MORLEY, R. 1994. Wife beating and modernization: the case of Papua New Guinea. Journal of Comparative Family Studies Vol. 25: 35-52

NATIONAL STATISTICAL OFFICE (NSO). 2002. Papua New Guinea Census 2000 Provincial Report-Madang. Port Moresby: The National Statistical Office.

ORSI, R. 1997. Everyday miracles: the study of lived religion. In Lived religion in America. Toward a history of practice, edited by David Hall, 3-21. New Jersey: Princeton University Press.

REED, A. 2003. Papua New Guinea's Last Place: Experiences of Constraint in a Postcolonial Prison. New York: Berghahn Books.

ROBBINS, J. 2004. Becoming sinners: Christianity and moral torment in a Papua New Guinea Society. Berkeley: University of California Press.

2005. The humiliation of sin: Christianity and the modernization of the subject among the Urapmin. In The making of global and local modernities in Melanesia. Humiliation, transformation and the nature of cultural change, edited by Joel Robbins and Holly Wardlow, 43-56. Hampshire, Burlington: Ashgate Publishing.

RUETHER, R. R. 1993. Sexism and God-Talk: Toward A Feminist Theology. Boston: Beacan Press.

SALA, H. 1999. 10-pela lo bilong marit. Wewak PNG: Christian books Melanesia Inc.

SCHMIDT, B. E. and I. W. SCHRÖDER. 2001. Introduction: Violent imaginaries and violent practices. In Anthropology of violence and conflict, edited by Bettina E. Schmidt and Ingo W. Schröder, pp. 1-24. London: Routledge.

SEPOE, O. 2000. Changing gender relations in Papua New Guinea. The role of women's organisations. India, New Delhi: UBS Publishers.

TOFT, S. 1985 (ed). Domestic violence in Papua New Guinea. Law Reform Commission Monograph 3. Boroko Papua New Guinea.

TOFT, S. 1985a. Marital violence in Port Moresby: Two urban case studies. In Domestic violence in Papua New Guinea, edited by S. Toft. Law Reform Commission Monograph no.3. Boroko.

1986. Domestic violence in urban Papua New Guinea. Occasional Paper 19, Law Reform Commission, Port Moresby.

TOFT, S. and S. BONNELL 1985. Marriage and domestic violence in rural Papua New Guinea, Occasional paper 18, Law Reform Commission, Port Moresby.

UMBERSON, D, ANDERSON, K., WILLIAMS, K. and CHEN, M.D. 2003. Relationship Dynamics, Emotion State, and Domestic Violence: A Stress and Masculinities Perspective. Journal of Marriage and Family 65 (February): 233-247.

VAZ, P. and K. BRUNO. 2003. Types of self-surveillance: From abnormality to individuals 'at risk'. Surveillance \& Society 1(3): 272-291.

ZIMMER-TAMAKOSHI, L. 1990. Sexual Exploitation and Male Dominance in Papua New Guinea. In Human Sexuality in Melanesian Cultures, edited by J. Ingebrittson, pp. 250-267. Point, Series No. 14, Melanesian Institute, Papua New Guinea.

1997. Wild Pigs and Dog Men: Rape and Domestic Violence as Women's Issues in Papua New Guinea. In Gender in Cross-Cultural Perspective, edited by Brettell and Sargent, pp. 538-553. Prentice-Hall.

2004. Rape and Other Sexual Aggression. In The Encyclopedia of Sex and Gender, edited by Carol Ember and Melvyn Ember, pp. 230-243. Kluwer: Academic Press. 